\title{
Problem-based learning on students' English learning interests
}

\author{
Siti Syafi'atul Qomariyah* and I Made Permadi Utama \\ Mandalika University of Education, Indonesia
}

\begin{abstract}
This study was conducted to find out how Problem Based Learning (PBL) affects students' English learning interests. The questionnaire is used as an instrument. The result of implementing the Problem Based Learning (PBL) method was that students felt enjoy and more interested. The students could develop their brainstorming when the teacher provided a problem to discuss with their group. They also created some ideas for solving their problem. Some students also provide their daily problems and make the classroom/discussion situation life. Based on data analysis showed that computing of the ttest was significant 0.000 . It means that applying Problem Based learning (PBLaffects students' learning interests. So, this method can be used as one of the alternative ways of teaching-learning to develop students' learning interests.
\end{abstract}

\section{ARTICLE HISTORY}

Received November 24, 2021

Accepted December 17, 2021

Published December 31, 2021

\section{KEYWORDS:}

Problem-based learning, English learning interests, Teaching-learning

\section{Introduction}

This period is the first time teaching-learning has been conducted in the classroom as long as covid 19. The teacher faced many problems which are caused by teaching-learning online before. We have shown that online is an alternative way to teach students during covid 19. Limitation of interaction with others is also one of the problems in teaching-learning online. Students only watch how the teacher teaches, explains the material, and gives assignments only online media. Students feel bored; they will ignore the lesson and find another activity such as playing a game, sleeping, doing something, etc. Based on the information above, the researchers tried to determine the objective of our study to solve that problem: to find out how Problem Based Learning (PBL) affects students' English learning interests.

Students commonly face the difficulty of maintaining learning interests in one lesson. Learning interests are usually up and down depending on the student's condition. To grow up students' interests, especially after online learning, the teacher applied suitable methods for teaching-learning, especially English subjects. A good method will help students to be accessible in learning. Teachers used the traditional method to teach during online learning. So, to make a good boaster for students' learning, the teacher wants to try to apply Problem Based Learning (PBL) method. The teacher is applying this method to students' learning interests because it could develop their skills, especially in English subjects, and students are more interactive. It is seeing relevance learning with their life. Moreover, PBL is designed to give students a good chance to increase their skills which have a goal such as collaborating in a group or team, developing oral and written skills, self-learning, implementing problem-solving materials in real life, awareness of responsibility and self-evaluation, individually work, explain a concept, learn group management and leadership responsibility, critical thinking and analysis, and develop information literacy (Nilson, 2010; Hmelo-Silver, 2004; HmeloSilver and Eberach, 2012; Amerstorfer, 2020; Ansarian and Teoh, 2018).

We could see from figure 1 the differences between the traditional method and the PBL method. The traditional method is a standard method used by teachers. They only provide the materials and directly teach learning activities. Students only receive the materials without 
developing brainstorming before they get it. The students only join the teacher's rule in the teachinglearning process. The traditional method is how to educate students using memorization and repetition of information; it means that there is no developing their decision-making skills, critical thinking, and problem-solving.

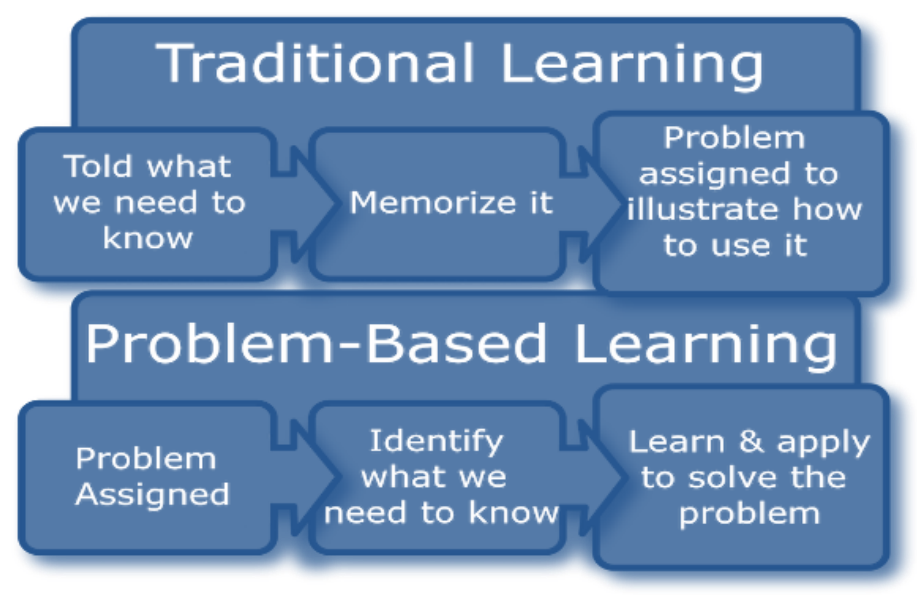

Figure 1. Traditional Method and PBL Method

Source: Educational Technology

Problem Based Learning (PBL) method is how to use or provide a teaching method to promote students' learning concepts and principles using complex real-world in the teaching-learning process as the vehicle to direct concepts and presentation of facts. In addition, to teach content, PBL could improve critical thinking skills, communication skills, and problem-solving abilities (Hmelo-Silver, 2004; Hmelo-Silver and Eberach, 2012, Ansarian and Teoh, 2018). Moreover, it also supported finding and evaluating research materials, and life-long learning could be provided in working groups (Duch et al., 2001;). PBL is a learning system that stands on students' problems when they get knowledge process. It has a critical function to be individually in finding problem-solving. PBL also has a valuable strategy for finding problem-solving in students' daily lives. Students can determine the kind of problem that has to solve. According to Duch et al. 1 (2001), there are some characteristics of PBL problem such as it must give motivate for students to understand the concept more deeply than their think, it must ask the students to make a good decision and to maintain them, it should connect to previous knowledge/courses to see content objectives, it needs to ensure that using a level of complexity, it should provide how students to open-ended and how students to provide problem-solving.

How is the teacher implementing Problem Based Learning (PBL) method? The researchers adapted from Abdalla and Gaffar (2011:15) stated there are three sessions of implementing Problem Based Learning (PBL) method as 1) first session is to solve the problem which is given to the students through Problem Based Learning is challenging knowledge and experience-making group discussion with their roles and responsibility every group, especially for a leader. Every session has 1-2 hours. Students will have several days to learn individually to manage the teacher's task. 2) the second session is to share students' results after learning individually before solving the problem. This session has a similar time to the first session, which is $1-2$ hours. The students are more active thinkers, cooperate, are responsible, study how to give information, and get feedback at the end of the learning process. 3) third session, the students could share the result in front of group discussion to get feedback from them, and also, they could also ask the expert suitable with the problem given before. 1-2 hours is the duration in this period.

There are four stages of the PBL method, namely 1) Basic Concepts; teacher explains basic knowledge consisting of the basic concept, instruction, sources, connection, and skills in every lesson. So, the students can catch the objective of the lesson. 2) Defining Problem; teacher describes the problem, and students respond with a brainstorming activity. It means that every student should give their idea and suggestion. This activity will get many problems that could be 
discussed. 3) Self Learning; every student should find many references from many resources such as magazines, newspapers, books, electronic media, etc. the aim of this point is students could find information sources and understand well about the problem and have the selfconfidence to describe issues in front of the class. 4) Knowledge Exchange; teacher asks the students to make a group to discuss references and determine problem-solving. Furthermore, 5) Assessment; it consists of cognitive, affective, and psychomotor. It also can see in figure 2.

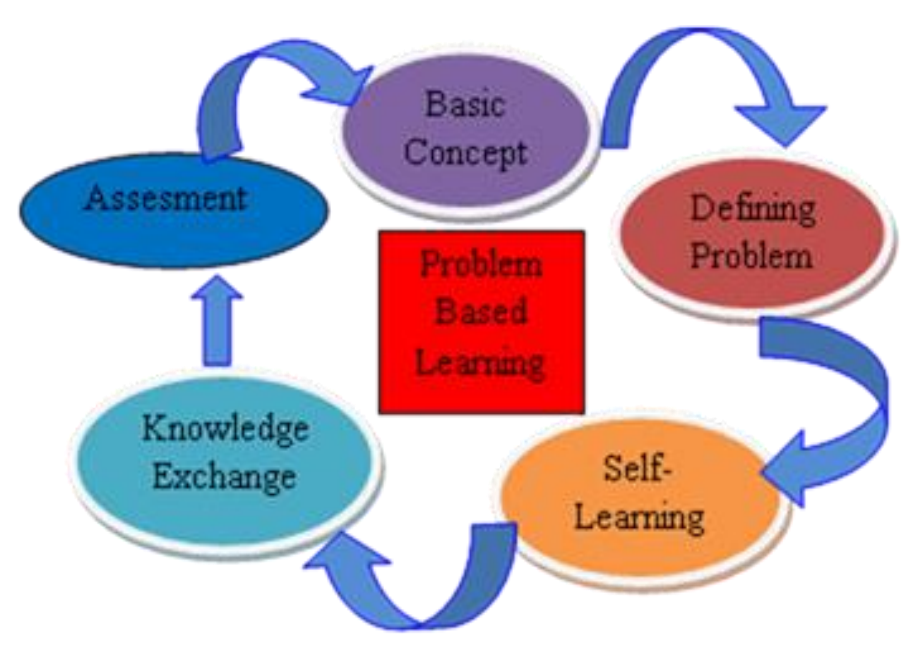

Figure 2. The Stages of PBL Method

The researchers tried to apply PBL to students' learning interests. According to Mangal (2007), interest is how the drives the whole machinery of teaching-learning is forced. Two kinds affect learning interests: 1) Internal factors, such as motivation, attention, ideal, and talent. 2) External factors, such as teachers, family, friends, and environment. The teacher can give treatment to grow students' learning interests, such as motivating them to learn, explaining what they can do at the end of the meeting, giving rewards to their achievement, and creating habitually good learning. Arikunto (1990) also stated when someone catches their eyes in the teaching-learning process; they need some elements. The role of interests in teaching-learning is for the concentration of thought and creating excitement. The function of interest in learning as a motivating force encourages students to learn.

Some researchers stated that the reader might not be confident about educational outcomes when applying a multifaceted approach (Charlin et al., 1998; Dolmans 2003; Lee, 2004). Many researchers applied PBL in large classes; the teachers have difficulty experience in improving students' interest and motivation, difficulty making students concentrate, and difficulty in connecting new content. Argaw et al. (2016) also applied PBL on large classes is 80 students. So, in this current study, the researchers tried to apply it in small classes. These varieties of PBL, the researchers needed to detail what factors affect the implementation of PBL, what factors affect learning interests of PBL, what happens in PBL environments, and what the outcomes of implementing PBL. The result of this research may help to improve their performance and practices. The analysis of PBL of the students is part of contributing PBL implementation to take ideas in the primary component. 


\section{Method}

The researchers used a quasi-experimental design. Quasi-experimental design is more suitable for real than true experimental. Establishing a cause-and-effect relationship between independent and dependent variables is the purpose of quasi-experimental design. Non randomize pretest-posttest design is used to conduct experimental research. It is used to conduct an organized classroom setting because the researcher will conduct without arranging and changing all the classes. The classroom design is suitable for the original class in the school. The process of conducted treatment in the class has similar time both experiment group and control group. It also has similar material.

All third-grade students in the academic year 2021/2022 were used as a population because this school is located in a village, so the number of students consisted of 44 students. We determined the sample using a purposive sampling technique consisting of 22 students as an experimental group and 22 students as a control group. In selecting the purpose of investigation, the sample is kind of the main point that will be used to select it (Kothari, 2004: 158). The instrument of this study used a questionnaire. The questionnaire was used to know students' interests. To collect the data, the researchers used pre-test and post-test.

After conducting pre-test and post-test data, the researcher computed the data using SPPS 18 to analyze the data. In analyses of the data, two kinds of data are conducted: descriptive analysis (finding mean score, mode, median, and standard deviation) and inferential analysis (finding hypothesis/t-test score). After the treatment of both the experimental and control groups and hypothesis analysis was compared at the .05 level of significance, it could be determined whether the independent variable (Problem Based Learning) affects the dependent variable (students' learning interests).

\section{Finding And Discussion}

The data analysis showed that the score of the pre-test control group (39.77) was lower than the experimental group (45.45). The post-test score was 53.86 (experimental group) and 47.72 (control group). It means that the experimental group had a higher score than the control whether we showed from pre-test or post-test. There was an increase between the experimental group and the control group. The computation of the post-test can see in table 1.

Table 1. Statistics

\begin{tabular}{lrrr}
\hline & & & Control Group \\
\hline $\mathrm{N}$ & Valid & Experimental Group & 22 \\
& Missing & 0 & 0 \\
Mean & & 53.8636 & 47.7273 \\
Median & 55.0000 & 47.5000 \\
Mode & 60.00 & 60.00 \\
Std Deviation & 6.53413 & 10.77113 \\
\hline
\end{tabular}

Implementing the Problem Based Learning (PBL) method was, students felt enjoy and more interested. The students could develop their brainstorming when the teacher provided a problem to discuss with their group. They also created some ideas for solving their problem. Some students also provide their daily problems and make the situation of classroom/discussion is life. The result of computing was significant in 0.000. it means that there is the effect of applying Problem Based learning (PBL) method toward students' learning interests. The analysis of the $t-$ test (hypothesis result) can be seen in table 2 . 
Table 2. Analysis of T-test

\begin{tabular}{lcccccc}
\hline & \multicolumn{6}{c}{ Test Value $=0$} \\
& $\mathrm{t}$ & $\mathrm{df}$ & $\mathrm{Sig}(2$-tailed) & $\begin{array}{c}\text { Mean } \\
\text { Difference }\end{array}$ & \multicolumn{2}{c}{$\begin{array}{c}\text { 95\% Confidence Interval } \\
\text { of the Difference }\end{array}$} \\
\cline { 6 - 7 } & & & & & Lower & Upper \\
\hline $\begin{array}{l}\text { Experimental } \\
\text { Group }\end{array}$ & 38.665 & 21 & .000 & 53.86364 & 50.9666 & 56.7607 \\
$\quad$ Control Group & 20.783 & 21 & .000 & 47.72727 & 42.9516 & 52.5029 \\
\hline
\end{tabular}

This research aims to determine the effect of Problem Based Learning (PBL) on students' learning interests. The result of data analysis showed that the score of the experiment group was higher than the control group. Analysis of t-test is significant in .000. It means that implementing the Problem Based Learning (PBL) method has a significant effect on students' learning interests. When we look at how Problem Based Learning (PBL) uses real-world problems to construct knowledge and improve the learning experience, it is suitable with the definition of Problem Based Learning (PBL) as an instructional strategy to find a meaningful solution (Rayne \& Symons, 2005; Capon \& Kuhn, 2004; Kuhn, 2015; McDowell, 2017). It also can see that Problem Based Learning (PBL) has some advantages, such as (1) It can force the students more interactive when the discussion is going. The students should give more ideas to contribute to problemsolving. (2) It can improve students more practice in oral communication than written. (3) It requires students to think critically. (4) It improves students' learning interests. The students like the atmosphere of the Problem Based Learning (PBL) learning process. (5) It can make students know new problems that never known before. The students can share the problem and knowledge with others. (6) It grows the spirit of cooperation with others. Students can learn how to work and solve together (cooperation, teamwork, and communication skills). However, learning is a process of getting knowledge. Learning interests is how the students develop their thinking ability. Kusmaryati \& Amertaningrum (2017) stated that when the students are getting paid attention, they provide good information efficiently and effectively strategies such as critical thinking, new knowledge, and deep structure. The students will bring their self-regulatory skills and hard work when they are interested in something.

In implementing Problem Based Learning (PBL), the teachers used four components of PBL, which adapted from Rayne \& Symons's (2005) theory. They explained as follows: (1) Group Work, students, work together in small groups and provide their level understanding of the material. The teachers can provide their groups, or the students can determine the groups independently. (2) Problem Solving, the teacher gives the problem based on the daily problem. It means the students face problems in their lives and try to solve them. (3) Discovering New Knowledge, students should have new knowledge to find a better solution. (4) Based on Real Life, the teacher encourages students to begin thinking like an expert. It will help the students most accessible to solve it. The students should try to think and solve the problem that is ever felt in their life.

It relates with a previous study by Khotimah (2014) she conducted on how problem-based learning can improve students' speaking ability. She has found that the implementation of PBL was easy for the students. They felt happy. The result of the study was a significant improvement; the score of speaking ability proved it. It means that the method that she has applied positively contributes to students' speaking ability. Bashith \& Amin (2017) also conducted research with applying Problem Based Learning (PBL) model on students' critical thinking skills and learning outcomes. In conducting the result of data analyses, the t-test is smaller than the significance level. However, the mean score of the experimental class is higher than the control class. So PBL becomes one of the alternative teaching models that enhance students' critical thinking skills. Mrayyan (2008) researched assessing students' learning preferences by applying problem-based learning (PBL) using vark. He measures the difference in learning style after introducing PBL as a teaching methodology. The result of multimodal preference on pre-test was $54 \%$, whereas on post-test was $68 \%$. He had found that more students could learn effectively when the teacher provided different learning activities. Active learning might be improved in the large classroom. Tambunan et al. (2018) conducted research applying PBL to improve students' outcomes. Their research is succeeded because the result of 
hypothesis analysis is high in a significant level. It is also proved by there is an interaction between e-learning and students outcomes. Seibert (2021) found that PBL also enhanced critical thinking and perseverance.

The similarities between the current study and the previous study are that the study showed that Problem Based Learning (PBL) might help students in learning interests and motivate them to think critically. Although one of the studies showed low significance, another showed a high score is proved by hypothesis analysis. Every process in teaching-learning, the PBL method gave the experience that was confirmed students' perception of their perseverance and appreciation. Perseverance provides opportunities for students not to quickly give up on the problems encountered during the learning process; students have shown their best academic performance (Lavy and Ovadia, 2016). In addition, Wolters and Hussain's (2015) found that perseverance demonstrated better self-efficacy, an effective way of learning and managing students' skills. Furthermore, appreciation is closely related to "recognition" in terms of value and meaning of events, appearances, behaviors, or even objects with a positive emotional sense of connection (Adler \& Fagley, 2005, p. 81). These things can influence students during the learning process; students can improve their interest in learning English by having a positive view on learning activities, materials, or even self-efficacy.

\section{Conclusion}

The researchers can conclude that implementing Problem Based Learning (PBL) is an effective method to increase students' learning interests. Based on data obtained and data analysis showed that this study is significant. Problem Based Learning (PBL) method has a good impact on the students, and also it can increase their learning interests. Otherwise, teachers can use other ways to increase students' learning interests, such as using various teaching-learning methods, using various teaching media, creating interactive learning styles to make the classroom is life, and giving rewards to motivate students more interested in learning. PBL method is an effective teaching method, especially in teaching English compared to the conventional/traditional teaching method. It is proved that the experimental group achieved better than the control group, where students found in the comparison group. In order to enhance the results of studies regarding the use of the PBL method, researchers hope that further research can find new things with a different scope that was not found in this study. The next researchers can investigate whether Problem Based Learning (PBL) method is effective on language skills, the internal-external factors that affect Problem Based Learning (PBL) method in language skills, or how the PBL method improves the students' psychology in learning. The maximum result of a few studies in applying the PBL method is hoped so that the results of this study can be a supporting source for further research on the PBL method

\section{References}

Abdallah, M.E., \& Abdurrahim, M.G. (2011). The Seven Steps of PBL Implementation. KSA: Jazan University.

Adler, M. G., \& Fagley, N. S. (2005). Appreciation: Individual differences in finding value and meaning as a unique predictor of subjective well-being. Journal of Personality, 73, 79-114.

Amerstorfer C. M. (2020). Problem-based learning for preservice teachers of English as a foreign language. Colloquium New Philol. 5, 75-90.

Ansarian, L., \& Teoh, M. L. (2018). Problem-based language learning and teaching: An innovative approach to learn a new language (pp. 53-64). Singapore: Springer.

Argaw, A.S., Haile, B.B., Ayalew, B.T., \& Kuma, S.G. (2016). The Effect of Problem Based Learning (PBL) Instruction on Students' Motivation and Problem Solving Skills of Physics. EURASIA Journal of Mathematics Science and Technology Education, 13(3), DOI 10.12973/eurasia.2017.00647a

Arikunto, S. (1990). Manajemen Pengajaran Secara Manusiawi. Jakarta: PT Rineka Cipta.

Bashith, A., \& Amin, S. (2017). The Effect of Problem Based Learning on EFL Students' Critical Thinking Skill and Learning Outcome. A- Ta'lim Journal, 24(2), https://doi.org/10.15548/jt.v24i2.271

Capon, N., \& Kuhn, D. (2004). What's so good about problem-based learning?. Cognition and instruction, 22(1), 61-79.

Charlin, B., Mann, K., \& Hansen, P. (1998). The many faces of problem-based learning: a framework for understanding and comparison. Medical Teacher, 20(4), 323-330. 
Duch, B.J., Groh, S.E., \& Allen, D.E.(Eds) (2001). The Power of Problem based Learning: Practical "How-to" for Teaching Undergraduate Courses in Any Discipline. Sterling, VA: Stylus.

Dolmans, D., Grave, W., Wolfhagen, I., \& Vleuten, C. (2005). Problem-based learning: future challenges for educational practice and research. Medical Education, 39, 732-741.

Hmelo-Silver, C. E. (2004). Problem-Based Learning: What and how do students learn? Educational Psychology Review, 16, 235-266.

Hmelo-Silver, C. E., \& Eberbach, C. (2012). Learning Theories and Problem-Based Learning. Problem-Based Learning in Clinical Education. Innovation and Change in Professional Education, 8, 1ᄀ17. https://doi.org/10.1007/978-94-007-2515-7_1.

Khotimah, S. (2014). The Use of Problem based Learning to Improve Students' Speaking Ability. Journal of English Language Teaching, 3(1), 50-56. https://doi.org/10.15294/elt.v3i1.4011

Kothari, C.R. (2004). Research Methodology: Method and Techniques. 2nd Edition. New Age International Publishers, New Delhi.

Kuhn, D. (2015). Thinking together and alone. Educational Researcher, 44, 46-53.

Kusmaryati, S.E., \& Amertaningrum, I.A. (2017). Exploring Students Interests in Learning English. The 2nd TEYLIN International Conference.

Lee, W. (2004). Exploring Professional Knowledge and Practices Collaboratively in Problem-based Discussions: Online and face-to-face discourses in a nursing class. Dissertation Abstracts International, 65(10), 3719A. (University Microfilms No. AAT3150017). Retrieved, March 15, 2007, from Digital Dissertations database.

Mangal, S.K. (2007). Essential of Education Psychology. New Delhi: Prentice hall

McDowell, M. (2017). Rigorous PBL by design: Three shifts for developing confident and competent learners. New York: Corwin.

Mrayyan, M.T. (2008). Problem Based Learning (PBL) Assessing Students' Learning Preferences Using Vark. Academia Edu.

Nilson, L.B. (2010). Teaching at Its Best. A research based Resource for College Instructors. JossyBass A Wiley imprint.

Lavy, S., \& Littman-Ovadia, H. (2016). My Better Self: Using Strengths at Work and Work Productivity, Organizational Citizenship Behavior, and Satisfaction. Journal of Career Development, 44. 10.1177/0894845316634056.

Rayne, D., \& Symons, S. (2005). Possibilities: A Practice Guide to Problem Based Learning in Physics and Astronomy. UK. University of Hull.

Seibert S. A. (2021). Problem-based learning: A strategy to foster generation $Z$ 's critical thinking and perseverance. Teaching and learning in nursing : official journal of the National Organization for Assciate Degree Nursing, 16(1), 85-88. https://doi.org/10.1016/j.teln.2020.09.002

Tambunan, L., Rusdi, R., \& Miarsyah, M. (2018). Effectiveness of Problem Based Learning Models by Using E-Learning and Learning Motivation toward Students Learning Outcomes on Subject Circullation Systems. Indonesian Journal of Science and Education, 2(1).

Wolters, C. A., \& Hussain, M. (2015). Investigating grit and its relations with college students' self-regulated learning and academic achievement. Metacognition and Learning, 10(3), 293311. https://doi.org/10.1007/s11409-014-9128-9. 